\title{
Breed, Age and Sex Wise-Distribution of Parvoviral Enteritis Among Canines Based on Loop-Mediated Isothermal Amplification Assay
}

\author{
Rincy M Ali*, Binu K Mani, Mini M, Priya PM and Vinod Kumar K
}

Department of Veterinary Microbiology, College of Veterinary and Animal Sciences, Kerala Veterinary and Animal Sciences University, Thrissur, Kerala, India

\begin{abstract}
The present study was undertaken to detect parvoviral infection among various breeds, age and sex of dogs using Loop-mediated isothermal Amplification (LAMP) assay. A total of 54 faecal samples collected from diarrheic dogs suspected for CPV infection were subjected LAMP assay using the specified primer sets. Out of the 54 samples collected, 39 (72.2\%) were found to be positive using the assay. Analysis of the collected data indicated that pups below five months of age group showed higher risk for CPV enteritis. Breed-wise distribution of CPV infection showed highest occurrence in Rottweilers when compared to other breeds. Also, the occurrence of CPV infections was noticed higher in male dogs than in females.
\end{abstract}

Keywords: Canine parvoviral diarrhea; Loop-mediated isothermal amplification; Parvoviral enteritis; Canines; Dogs; Parvoviral infection

\section{Introduction}

Canine parvoviral infection is one of the most significant viral causes responsible for neonatal death in pups [1]. The causative agent behind this was found to be CPV-2 causing high morbidity and frequent mortality among the infected dogs [2]. As per International Committee for Taxonomy of Virus (ICTV) 2013, CPV is classified as Carnivore protoparvovirus 1 in the genus Protoparvovirus of the family Parvoviridae. The CPV-2 was emerged in late 1970s and few years after its emergence, it was found that there were two antigenic variants designated as CPV-2a and CPV-2b which are now distributed worldwide [3]. There are many reports documenting the prevalence of $\mathrm{CPV} 2 \mathrm{a}$ and $2 \mathrm{~b}$ infection in various parts of India, especially in Kerala [4] West Bengal [5] Pondicherry etc. [6].

Among the various diagnostic aids, Loop mediated isothermal amplification (LAMP) is a novel nucleic acid amplification technique to amplify specific DNA sequence and the technique is simple, cost effective alternative to PCR under isothermal condition with product visible to naked eye [7]. The basic principle of this technique is auto cycling strand displacement DNA synthesis using specific polymerase enzyme with high strand displacement activity like Bst polymerase. Here amplification can be detected by observing directly the turbidity, the fluorescence after adding DNA-binding dyes like Propidium iodide or by the presence of ladder-like multiple bands on $2 \%$ agarose gel Even though there are reports indicating dogs of all ages, breeds and sex could be susceptible for CPV infection [8] studies by many workers showed that dogs below six months were commonly affected [7,9]. Ernst and Glickman reported equal susceptibility for CPV enteritis among all breeds of dogs, however, [9] Glickman opined that Rottweilers and Doberman pinchers showed higher percent of infection compared to other breeds which is in accordance with the findings of Rogers and Houston [10,11] emphasized CPV incidence in breeds such as Rottweilers, Bull terriers, Doberman pinschers, and German shepherd dogs was higher compared to Toy poodles and Cocker spaniels.

According to Ramadass et al. [8-10] both sexes were equally susceptible for developing CPV infection. Houston [11] detected that the incidence of CPV infection was higher in sexually intact dogs than in neutered dogs.

\section{Materials and Methods}

\section{Collection of sample}

Fifty-four feacal samples were collected from diarrheic dogs suspected for canine parvoviral infection that were brought to teaching veterinary clinical complexes of Kerala Veterinary and Animal Science University situated at Mannuthy and Kokkalai. The animals were showing profuse diarrhea with fetid odor and the fecal samples were mixed with blood. The samples were collected during January 2014 to July 2015. Detailed case history with special reference to age, breed and sex were also gathered. Sterile rectal swabs were used for collection of samples and after collection, the swabs were immersed in $1.5 \mathrm{~mL}$ of sterile PBS of $\mathrm{pH}$ 7.2.

\section{LAMP assay}

The template DNA was prepared using crude method of boiling and chilling. Briefly, the fecal samples immersed in PBS were clarified by centrifugation at $9500 \times \mathrm{g}$ for $15 \mathrm{~min}$. at $4^{\circ} \mathrm{C}$ in a cooling centrifuge (Dynamica). Two hundred microlitres of the clarified faecal suspension was boiled at $96^{\circ} \mathrm{C}$ for $10 \mathrm{~min}$ and chilled immediately in crushed ice [12]. Then the sample was centrifuged at $3000 \times \mathrm{g}$ for $10 \mathrm{~min}$ in a cooling centrifuge (Remi C-24). LAMP technique was performed as per the protocol described by Ref. [13]. LAMP was performed in $25 \mu \mathrm{l}$ total reaction volume containing extracted DNA (template), Forward outer primer (F3, 5' GTAAACCATGTAGACTAACACAT 3'), Backward outer primer (B3, 5' GCACTATAACCAACCTCAGC3'), Forward inner primer (FIP GCTCCTTCAGATTGAGGCAAAGACATGGCAAACAATAGAGCA), Backward inner primer (BIP, GTTCAACAAGATAAAAGACGTGGGGTCTCATAATAGTAGCTTCAGT),

*Corresponding author: Rincy M Ali, Department of Veterinary Microbiology, College of Veterinary and Animal Sciences, Kerala Veterinary and Animal Sciences University, Thrissur, Kerala, India, Tel: 9495763717; E-mail: rinsrincy@gmail.com

Received October 07, 2016; Accepted November 16, 2016; Published March 15, 2016

Citation: Rincy MA, Mani BK, Mini M, Priya PM, Vinod Kumar K (2016) Breed, Age and Sex Wise-Distribution of Parvoviral Enteritis Among Canines Based on LoopMediated Isothermal Amplification Assay. Immunochem Immunopathol 3: 124. doi: 10.4172/2469-9756.1000124

Copyright: ( 2016 Rincy MA, et al. This is an open-access article distributed under the terms of the Creative Commons Attribution License, which permits unrestricted use, distribution, and reproduction in any medium, provided the original author and source are credited. 
Citation: Rincy MA, Mani BK, Mini M, Priya PM, Vinod Kumar K (2016) Breed, Age and Sex Wise-Distribution of Parvoviral Enteritis Among Canines Based on Loop-Mediated Isothermal Amplification Assay. Immunochem Immunopathol 3: 124. doi: 10.4172/2469-9756.1000124

Page 2 of 4

deoxynucleotide triphosphates, $\mathrm{MgSO}_{4}$, Betaine, Bst DNA polymerase large fragment and sterile triple distilled water. Except betaine (Sigma-Aldrich), all the other reagents were obtained from New England Biolabs. LAMP was performed by preparing reaction mixture. The template DNA was prepared from the faecal samples by boiling and chilling. LAMP technique was performed in $25 \mu$ l total reaction volume containing $5 \mu \mathrm{l}$ of extracted DNA (template), one $\mu \mathrm{l}$ (40 pmol) each of FIP and BIP, one $\mu \mathrm{l}(5 \mathrm{pmol})$ each of F3 and B3, $2.5 \mu \mathrm{l}$ of a $10 \mathrm{X}$. ThermoPol reaction buffer, $3.5 \mu \mathrm{l}$ of $1.4 \mathrm{mmol} / \mathrm{ml}$ deoxynucleotide triphosphates, $1.5 \mu \mathrm{l}$ of $8 \mathrm{mmol} \mathrm{MgSO}_{4}, 4 \mu \mathrm{l}$ of $0.8 \mathrm{~mol}$ betaine, one $\mu \mathrm{l}$ of $8 \mathrm{U}$ Bst DNA polymerase large fragment and $4.5 \mu \mathrm{l}$ of sterile triple distilled water. The whole isothermal reaction was performed in a simple water bath by incubating the reaction mixture at $63^{\circ} \mathrm{C}$ for $60 \mathrm{~min}$.

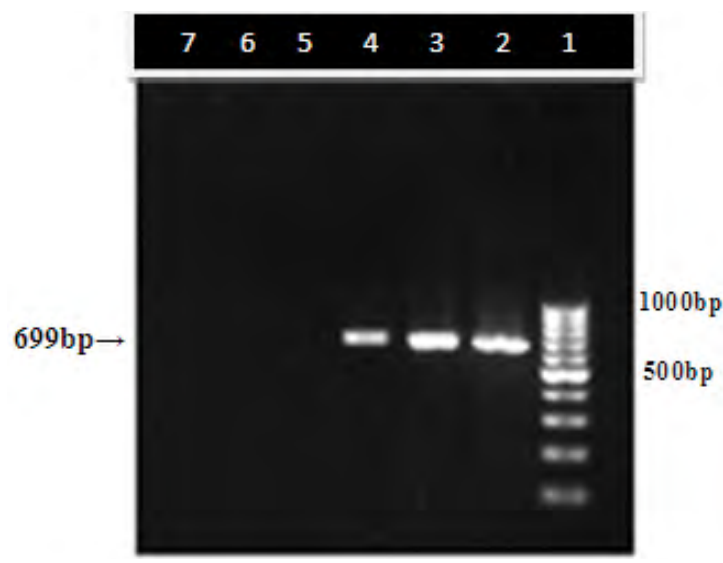

Figure 1: Agarose gel electrophoresis analysis of PCR products of CPV suspected faecal samples.

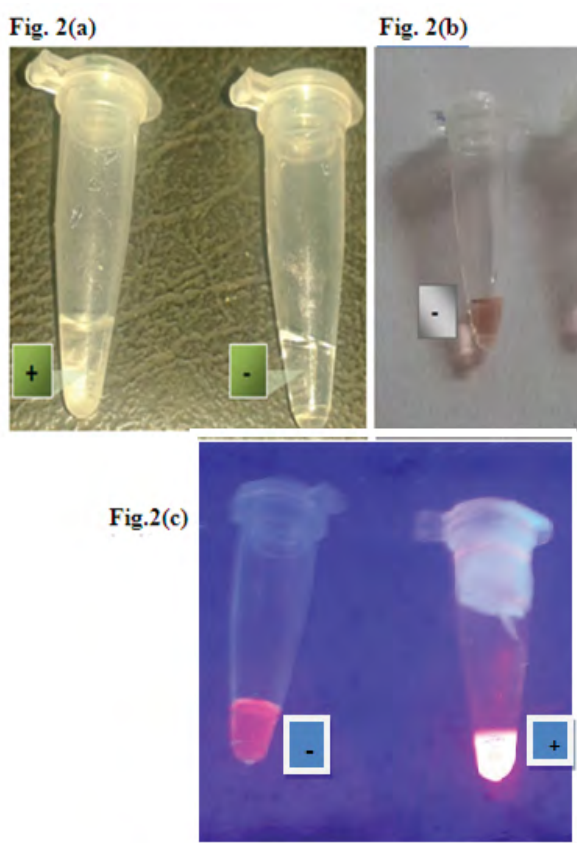

Figure 2: Test results of LAMP products. a) Positive result (left) showing turbidity and negative control (right). b) Propidium iodide added LAMP reaction tubes (under ambient light): negative control with reddish orange colour (left) and positive sample with pink colour (right). c) Propidium iodide added LAMP reaction tubes (under UV light): negative control without fluorescence (left) and positive sample with fluorescence (right).

\begin{tabular}{|c|c|c|c|}
\hline $\begin{array}{c}\text { Age in } \\
\text { months }\end{array}$ & $\begin{array}{c}\text { Number of samples } \\
\text { tested }\end{array}$ & $\begin{array}{c}\text { Number tested } \\
\text { positive }\end{array}$ & $\begin{array}{c}\text { Age-wise } \\
\text { incidence }\end{array}$ \\
\hline $0-4$ & 25 & 21 & 84.00 \\
\hline $5-8$ & 17 & 11 & 64.70 \\
\hline Above 9 & 12 & 7 & 58.33 \\
\hline Total & 54 & 39 & 72.20 \\
\hline
\end{tabular}

Table 1: Age-wise distribution of CPV infection in clinically suspected cases by LAMP assay.

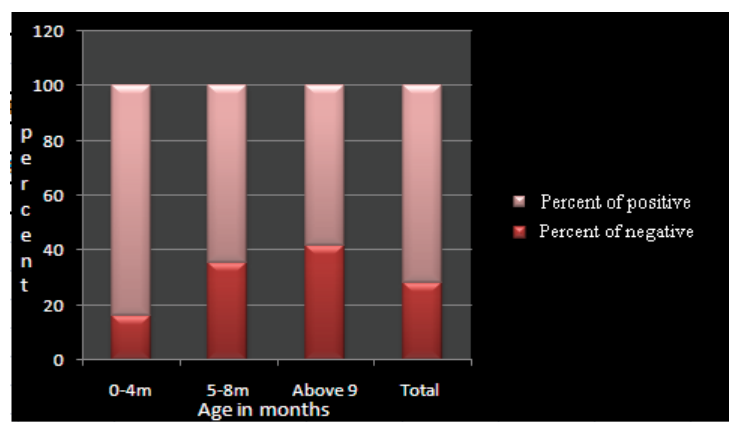

Figure 3: Graphical representation of age-wise distribution of CPV infection in clinically suspected cases by LAMP assay.

\begin{tabular}{|c|c|c|c|}
\hline Breed & $\begin{array}{c}\text { Number of samples } \\
\text { tested }\end{array}$ & $\begin{array}{c}\text { Number tested } \\
\text { positive }\end{array}$ & $\begin{array}{c}\text { Breed-wise } \\
\text { incidence }\end{array}$ \\
\hline Rottweiler & 11 & 9 & 81.81 \\
\hline $\begin{array}{c}\text { German } \\
\text { shepherd }\end{array}$ & 10 & 8 & 80.00 \\
\hline Labrador & 6 & 4 & 66.77 \\
\hline Non-descript & 6 & 4 & 66.77 \\
\hline $\begin{array}{c}\text { Doberman } \\
\text { pinscher }\end{array}$ & 13 & 8 & 61.54 \\
\hline Other breeds & 8 & 6 & 75.00 \\
\hline Total & 54 & 39 & 72.22 \\
\hline
\end{tabular}

Table 2: Breed-wise distribution of CPV infection in clinically suspected cases by LAMP assay.

\section{Results and Discussion}

Among the 54 samples tested using LAMP, 39 samples were found (72.2\%) positive for parvovirus (Figures 1 and 2).

\section{Age-wise distribution of CPV infection}

The age wise comparison of the occurrence of CPV infection among the examined samples are shown in the Table 1 and Figure 3. The present study revealed that pups below five months of age group (84.00 per cent) showed higher occurrence of CPV enteritis, followed by dogs of five to eight months ( 64.70 per cent). The dogs above nine months of age (58.33\%) showed least occurrence of CPV.

\section{Breed-wise distribution of CPV infection}

The incidence of CPV infection among the different breeds are represented in the Table 2 and Figure 4. Among the samples screened for CPV, the highest incidence of CPV infection was noted among the Rottweilers (81.0\%), followed by German shepherd (80.00 per cent). Also, the disease was prevalent among Labradors (66.77 percent), nondescripts (66.77\%) and Doberman pinscher (61.54\%).

\section{Sex-wise distribution of CPV infection}

Analysis was done based on results the observed separately in male and female animals (Table 3; Figure 5). The results revealed that the 
Citation: Rincy MA, Mani BK, Mini M, Priya PM, Vinod Kumar K (2016) Breed, Age and Sex Wise-Distribution of Parvoviral Enteritis Among Canines Based on Loop-Mediated Isothermal Amplification Assay. Immunochem Immunopathol 3: 124. doi: 10.4172/2469-9756.1000124

Page 3 of 4

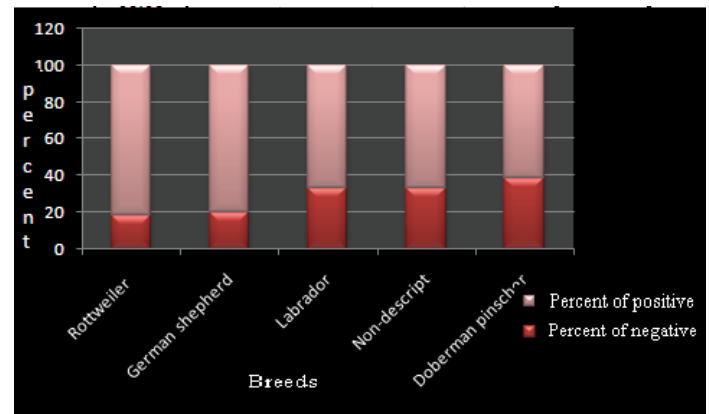

Figure 4: Graphical representation of breed-wise distribution of CPV infection in clinically suspected cases by LAMP assay.

\begin{tabular}{|c|c|c|c|}
\hline Sex & $\begin{array}{c}\text { Number of samples } \\
\text { tested }\end{array}$ & $\begin{array}{c}\text { Number tested } \\
\text { positive }\end{array}$ & $\begin{array}{c}\text { Sex-wise } \\
\text { incidence }\end{array}$ \\
\hline Male & 31 & 25 & 80.65 \\
\hline Female & 23 & 14 & 60.87 \\
\hline Total & 54 & 39 & 72.22 \\
\hline
\end{tabular}

Table 3: Sex-wise distribution of CPV infection in clinically suspected cases by LAMP assay.

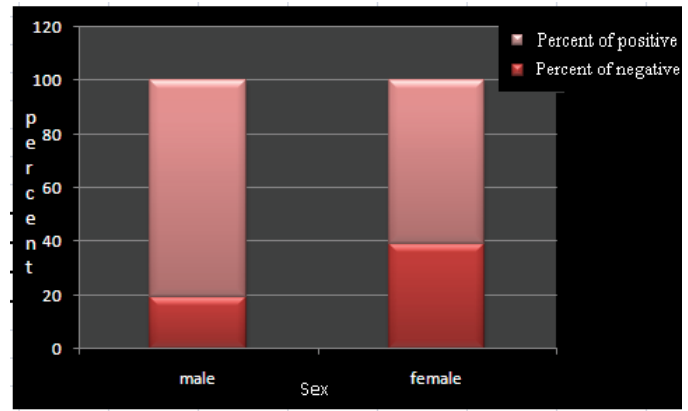

Figure 5: Graphical representation of sex-wise distribution of CPV infection in clinically suspected cases by LAMP assay.

occurrence of CPV infections was higher in male dogs $(80.65 \%)$ than in females $(60.87 \%)$.

\section{Conclusion}

Parvoviral enteritis caused by canine parvovirus type 2 (CPV-2) is an acute and highly contagious disease causing high morbidity and mortality in dogs. Early diagnosis of the disease is essential so that therapy can be initiated at an early stage, thus minimizing mortality rate. In the present study, by LAMP assay 39 samples (72.22\%) were detected as positive among the 54 samples screened for CPV infection. In a previous study Cho [14] identified LAMP assay was more sensitive and specific in detecting CPV from faecal samples.

Present study indicated that the CPV infection is distributed mostly among pups under five months of age (84.00\%), while infection among the dogs above nine months of age was found to be less (58.33\%). Khan et al. [15] opined that factors like lack of maternal immunity and poor immune-competency predispose the pups under five months of age for parvo infection. All the pups observed in the present study were weaned. Results of the present study and that of the previous researches Rogers, Houston, Khan and Castro $[10,11,15,16]$ on effect of age of animal for CPV infection revealed that more than 50 per cent of the affected animals were below 5 months of age.

Among the samples screened for CPV, the highest incidence of
CPV infection was noted in Rottweilers (81.0\%), followed by German shepherd $(80.00 \%)$. Many studies indicated that Rottweilers showed higher per cent of infection compared to other breeds [9-11]. which is in accordance with the present findings. Some studies emphasized that the occurrence of CPV infection was more in German shepherd dogs than in other breeds [17-20]. Likewise, in the present study German shepherd dogs were the second most affected breeds as far as CPV infection was concerned.

In this study, the occurrence of CPV infections was higher in male dogs $(80.65 \%)$ than in females $(60.87 \%)$. A higher incidence of parvoviral enteritis in males than in females was also reported $[2,21,22]$. The higher incidence of CPV in males was attributed to the habit of males, which travel more than females, thereby getting more exposed to parvo infected faeces [22] and are thereby more prone for CPV infection $[23,24]$.

\section{References}

1. Parrish CR (1999) Host range relationships and the evolution of canine parvovirus. Veterinary Microbiology 69: 29-40.

2. Srinivas VMV, Mukhopadhyay HK, Thanislass J, Antony PX, Pillai RM, et al. (2013) Molecular epidemiology of canine parvovirus in southern India. Veterinary World 6: 744-749.

3. Deepa PM (1999) Seroprevalence and diagnosis of canine parvoviral infection Kerala Agricultural University, Vellanikkara, p: 159.

4. Gagnon AN, Povey RC (1979) A possible parvovirus associated with an epidemic gastro-enteritis of dogs in Canada. Veterinary Record 104: 263-264.

5. Notomi T, Okayama H, Masubuchi H, Yonekawa T, Watanabe K, et al. (2000) Loop mediated isothermal amplification of DNA. Nucleic Acids Research 28: 63.

6. Eugster AK, Bendele RA, Jones LP (1978) Parvovirus infection in dogs. Journal of the American Medical Association 173: 1340-1341.

7. Ernst S, Montest S, Martin R (1988) A retrospective epidemiological study of the risk factors associated with the occurrence of parvovirus infection in a canine hospital population. Archivos De Medicina.

8. Ramadass P, Khader TGA (1982) Diagnosis of canine parvovirus infection by agar gel precipitation test and fluorescent antibody technique. Cheiron 1: 323-328.

9. Glickman LT, Domanski LM, Patronek FJ, Visintainer F (1985) Breedrelated risk factors for canine parvovirus enteritis. Journal of the American Medical Association 187: 589-594.

10. Rogers S (1987) Canine parvovirus infection in Zimbabwe, incidence and control. Zimbabwe Veterinary Journal 18: 34-41.

11. Houston DM, Ribble CS, Head LL (1996) Risk factors associated with parvovirus enteritis in dogs: 283 cases (1982-1991). Journal of the American Medical Association 208: 542-546.

12. Schunck B, Kraft W, Truyen U (1995) A simple touch-down polymerase chain reaction for the detection of canine parvovirus and feline panleukopenia virus in feces. Journal of Virological Methods 55: 427-433.

13. Parthiban S, Mukhopadhyay H, Antony PX, Pillai RM (2010) Molecular typing of canine parvovirus occurring in Pondicherry by multiplex PCR and PCR-RFLP. Indian Journal of Virology 21: 86-89.

14. Cho H, Kang J, Park N (2006) Detection of canine parvovirus in faecal samples using loop-mediated isothermal amplification. Journal of Veterinary Diagnostic Investigation 18: 81-84

15. Khan MA, Rabbni M, Muhammad K, Murtaza N, Nazir J (2006) Isolation and characterization of canine parvovirus. Indian Journal of Agriculture Biology 8 898-900.

16. Castro TX, Miranda SC, Labarthe NV, Silva LE, Garcia RCN, et al. (2007) Clinical and Epidemiological aspects of canine parvovirus enteritis in the state of Rio de Janeiro: 1995-2004. Arq Bras Med Vet Zootec 59: 333-339.

17. Mukhopadhyay HK, Amsaveni S, Matta SL, Antony PX, Thanislass J, et al (2012) Development and evaluation of loop-mediated isothermal amplification assay for rapid and sensitive detection of canine parvovirus DNA directly in faecal specimens. Letters in Applied Microbiology 56: 23-30. 
Citation: Rincy MA, Mani BK, Mini M, Priya PM, Vinod Kumar K (2016) Breed, Age and Sex Wise-Distribution of Parvoviral Enteritis Among Canines Based on Loop-Mediated Isothermal Amplification Assay. Immunochem Immunopathol 3: 124. doi: 10.4172/2469-9756.1000124

Page 4 of 4

18. Mathew J (2004) Polymerase chain reaction for the detection of canine parvovirus in faeces of dogs. Kerala Agricultural University, Thrissur, Kerala, p: 114

19. Kumar M, Nandi S, Chidri S (2010) Development of a polyclonal antibody-based AC-ELISA and its comparison with PCR for diagnosis of canine parvovirus infection. Virology Science 25: 352-360.

20. Haque S, Arfa T (2012) Epidemiological study of parvo gastroenteritis and its management by different concentrations of fluid in pups. Indian Journal of Canine Practice 4: 83-85.

21. Basheer M (2011) Detection of antigenic variants of canine parvovirus by polymerase chain reaction and sequencing. College of Veterinary and Animal Sciences, Mannuthy, Kerala, p: 129

22. Truyen U, Platzer G, Parrish CR (1996) Antigenic type distribution among canine parvoviruses in dogs and cats in Germany. Veterinary Record 138: 365-366.

23. Biswas S, Das PJ, Ghosh SK, Pradhan NR (2006). Detection of canine parvovirus (CPV) DNA by polymerase chain reaction and its prevalence in dogs in and around Kolkata, West Bengal. Indian Journal of Animal Sciences 76: $324-325$

24. Pereira CAD, Leal ES, Durigon E (2007) Selective regimen shift and demographic growth increase associated with the emergence of high-fitness variants of canine parvovirus. Infection, Genetics and Evolution 7: 399-409. 